\title{
STROKE IN ANCIENT TIMES
}

\section{A reinterpretation of Psalms 137:5,6}

\author{
Luiz Antonio de Lima Resende', Silke Anna Theresa Weber ${ }^{2}$, \\ Marcelo Fernando Zeugner Bertotti', Svetlana Agapejev ${ }^{7}$
}

\begin{abstract}
Stroke was probably first described in Psalms 136: 5-6 of the Catholic Bible, and Psalms 137:5-6 of the Evangelical Bible. Based on the Portuguese, Spanish, English, German, Dutch, Russian, Greek, and original Hebrew Bible, the significance of this Psalm is the invocation of a punishment, of which the final result would be a stroke of the left middle cerebral artery, causing motor aphasia and right hemiparesis.
\end{abstract}

KEY WORDS: stroke, history, Bible.

\begin{abstract}
Acidente vascular cerebral nos velhos tempos: uma reinterpretação dos Salmos 137 (versículos 5,6)
Resumo - Acidente vascular cerebral foi descrito pela primeira vez provavelmente na Bíblia, nos Salmos 136, versículos 5 e 6, da bíblia católica, e 137, versículos 5 e 6, da bíblia evangélica. Nas bíblias escritas em português, espanhol, inglês, alemão, holandês, russo, grego e no original hebraico, o significado destes Salmos seria a invocação de um castigo, que poderia corresponder a acidente vascular da artéria cerebral média esquerda, levando a afasia motora com hemiplegia direita.
\end{abstract}

PALAVRAS-CHAVE: acidente vascular cerebral, história, Bíblia.

In 1861, Pierre Paul Broca reported his patient Leborgne "Tan-tan", who presented motor aphasia and right hemiplegia after lesion on the left frontal inferior gyrus'. This description is considered a milestone in the history of neurology, but there is evidence that more than 2000 years ago these symptoms were described in the book of Psalms, in the Bible?

The Bible is considered by many to be the first major encyclopedia written by man. Psalm 136 was probably written about 500 to 600 years before Christ, and relies on punishment for those who forget Jerusalem ${ }^{3}$.

The aim of this study is to discuss this psalm's contribution to the history of neurology.

\section{METHOD}

Comparisons were made between different Bible sources written in Portuguese, Spanish, English, Dutch, Russian, Greek, and the original Hebrew, in an attempt to find the best translation of Psalm 137, verses 5 and 6 (Evangelical Bible) or Psalm 136, verses 5 and 6 (Catholic Bible). The original Hebrew version was extracted from the Codex Leningradensis, dated $1008 \mathrm{AD}$, written on papyrus by Aaron ben Moses ben Asher, "The Instructor"

\section{RESULTS}

Psalm 137 from the Evangelical Bible corresponds exactly to Psalm 136 in the Catholic Bible; Psalms 9 and 10 are merged in the Catholic Bible.

Texts of the Psalm 137, verse 5 and 6:

a) Catholic Bible (Version 1, in Portuguese) ${ }^{6}: 5$ - Se eu me esquecer de ti, Oh Jerusalém, que a minha mão direita se paralise; 6 Que minha lingua se me apegue ao paladar, se eu não me lembrar de ti, se não puser Jerusalém acima de todas as minhas alegrias...

b) Catholic Bible (Version 2, in Portuguese) ${ }^{7}: 5$-Se te olvidar, Jerusalém, fique paralisada a minha destra; 6- apegue-se minha língua ao palato se não me lembrar de ti, se não puser Jerusalém acima de todas as minhas alegrias...

c) Evangelical Bible (in Portuguese) 8 : 5 - Se eu me esquecer de ti, Oh Jerusalém, que se resseque a minha mão direita; 6 - Apegue-se-me a língua ao paladar, se não me lembrar de ti, se não preferir Jerusalém à minha maior alegria...

d) Spanish version by Matthew Henry, one of the most important "puritans"3: 5 - Si me olvido de ti, Oh Jerusalén, que mi diestra olvide su arte; 6 - Que mi lengua se pegue a mi paladar, si de ti no me acuerdo com amor y respeto, si no enaltezco a Jerusalén como preferente asunto de mi alegria... 
A 5 Sergefie id, bein, * Serufalem; fo werde

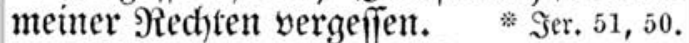
6 Meine * Zunge muffe an meintem (Saument fleben, wo idh beiner nidyt ges bente, wo idh nidyt laffe Sertifalem meme hüdjifte žreute feitr.
В 5 Если зг забуду тебл, Иерусалим, забудь меня десница моя.

6 Прильпни язык мой к гортани моей, если не буду помнить тебя, если не поставлю Иерусалима во главе веселия моего.

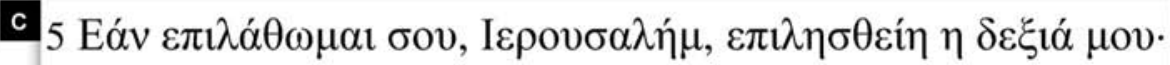

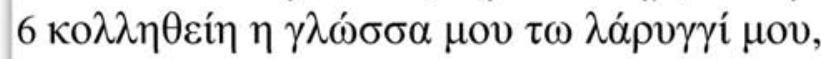

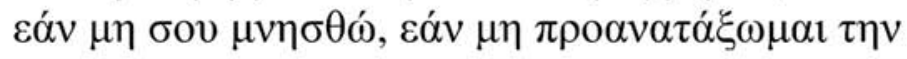

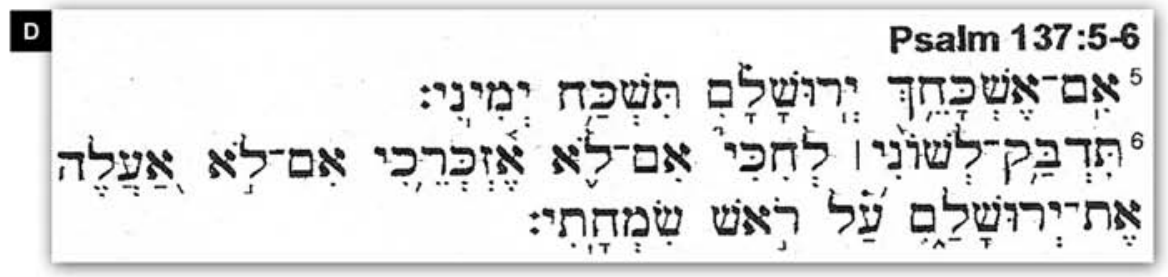

Figure. (A) Old germanic bible (text from Martin Luter); (B) Russian Bible; (C) Greek Bible; (D) Psalms 137:5-6, from Codex Leningradensis. There are several possibilities of traduction, mainly 5 - "If I forget you, Oh Jerusalem, let my right hand (my right hand side) wither(paralysed) 6 - Let my tongue cleave to my mouth, if I do not remember you, if I do not set Jerusalem above my highest joy".

e) English Bible': 5 - If I forget you, O Jerusalem, let my right hand wither! 6 - Let my tongue cleave to the roof of my mouth, if I do not remember you, if I do not set Jerusalem above my highest joy!

f) Modern German Bible ${ }^{10}: 5$ - Vergesse ich Dich, Jerusalem, so verdorre meine Rechte. 6 - Meine Zunge soll an meinem Gaumen kleben, wenn ich Deine nicht gedenke, wenn ich nicht lasse Jerusalem meine höchste Freude sein." 5 - "If I forget you, Jerusalem, my right hand side shall dry up, 6- my tongue shall stick to my palate, if I do not remember you, if I do not permit Jerusalem to be my greatest joy..."

g) Ancient German Bible, corresponding to a translation by Luther": 5 - Vergesse Ich Dein, Jerusalem, so werde meiner Rechten vergessen; 6 - Meine Zunge müsse an meinem Gaumen kleben, wo ichDdeiner nicht gedenke, wo ich nicht lasse Jerusalem meine höchste Freude sein." 5 - If I forget you, Jerusalem, the right side of my body will be forgotten; 6 - so that my tongue shall stick to my palate, if I do not remember you, if I do not permit Jerusalem to be my greatest joy...

h) Dutch Bible ${ }^{12}: 5$ - Mijn rechterhand mag verlamd raken, als ik Jeruzalem zu vergeten! 6 - Als ik Jeruzalem niet zou bezingen als de mooiste en hoogste stad, zou mijn tong krachteloos in mijn mong mogen liggen.. 5 - My right hand shall be paralysed, if I forget Jerusalem, 6 - If I do not sing to Jerusalém as the most beautiful and highest city, my tongue shall lie weakended in my mouth...

The versions written in German, Russian, $\mathrm{Greek}^{13}$ and Hebrew are shown in Figure.

\section{DISCUSSION}

Focusing on the history of neurology, two language versions seem to be crucial for our analysis: 1) the version by Martin Luther, for its historical importance, and 2) the Greek Bible. The so called "original" Hebrew Bible which we find nowadays was compiled in Cairo more than 1,000 years after its original writing. For 500 years, the manuscript was kept by the Massoreta, one of the major scribe groups in antiquity. But the original manuscripts may have been modified during this 1,000 year period, the most well known is the introduction of Hebrew vowels by the Massoreta about 500 to 600 AD. Until this time, Hebrew writing consisted only of consonants ${ }^{14}$. This may be one reason why there is more than one translation version the original Hebrew Bible ${ }^{5}$. The Martin Luther and Greek Bible versions are based on the "Septuaginta". It is known as Septuaginta (LXX) a Greek version of the Old Testament, dated from 300 to $200 \mathrm{BC}$, written by 72 scholars in the Egyptian city of Alexandria, from where its name originates $^{14}$.

In Luther's version, "If I forget you, oh Jerusalem, my right shall be forgotten - meiner Rechten vergessen," he probably describes a right hemiplegia. In the Greek version, "If I forget you oh Jerusalem, my right hand shall also be forgotten. My tongue shall stick to my palate, if I do not remember you, if I do not celebrate Jerusalem as the apex of my joy ${ }^{13 "}$ - the paralysis is limited to the right hand. 
A comparison between Portuguese texts and those in Spanish, English, German, Dutch, Russian, Greek, and Hebrew permits the following translation of Psalm 137, verses 5 and 6: "If I forget of you, oh Jerusalem, my right hand (my right side) shall dry, be paralyzed, loose its ability, its dexterity... That my tongue shall stick (shall be weakened, arrested) to my palate (in my throat), if I remember you, if I do not permit Jerusalem to be my greatest joy (if I do not sing of Jerusalem as my greatest joy)". For Benton and Joynt ${ }^{2}$, the tongue stuck on the palate or throat is one of the earliest descriptions of motor aphasia.

As a neurologist, the symptoms of the right hand or forgotten or paralyzed side associated to tongue immobility describe the classic form of stroke with right hemiplegia and motor aphasia. Stroke is a prevalent clinical condition in modern times, and should also have been so in antiquity.

In this way, a neurologist would understand the Psalm as "If I forget you, oh Jerusalem, I will suffer a stroke of the left middle cerebral artery, causing motor aphasia and right hemiplegia, if I do not remember you, if I do not keep Jerusalem as my greatest joy."

This is the best interpretation for the authors, but would perhaps only be understood by neurologists.

Psalm 137 is a relevant contribution from Hebrew culture to the history of neurology. Is this description of a punishment corresponding to the symptoms found in cerebrovascular stroke of the middle cerebral artery a coincidence? Or did the Hebrews know at that time that left hemiplegia may occur without aphasia, did they know of cerebral dominance about 600 years before Christ?

ACKNOWLEDGEMENTS - Our special thanks to Gritje Couperus, Professor of Theology, to Helena Euthymios Sazalis, official translator for the Greek language, and to Reverend Ricardo César Toniolo, for their translations of the Dutch, Greek, and Hebraic versions, respectively. Their contributions were highly relevant to this study.

\section{REFERENCES}

1. Castaigne P, Lhermitte F, Signoret JL, Abelanet R. Description et étude scanographique du cerveau de Leborgne: la découverte de Broca. Rev Neurol (Paris) 1980; 136:563-583.

2. Benton AL, Joynt RJ. Early descriptions of aphasia. Arch Neurol 1960; 3:205-222.

3. Lacueva F. Comentario exegético-devocional a toda la bíblia. Livros Poéticos - Salmos. Tomo I. Barcelona M.C.E. Horeb, 1983:470-471.

4. Francisco EF. Manual da Bíblia Hebraica. Introdução ao texto massotérico. Ed. 2, Vida Nova: São Paulo, 2005. http:/ / pt.wikipedia.org/wiki/ Codex Leningrad.

5. Toniolo RC, Pastor da Igreja Presbiteriana do Calvário, de Botucatu, comunicação pessoal, 2007.

6. Castro JP. Bíblia Sagrada. 157ª ed., São Paulo Ave-Maria Ed. , 2003

7. Pontifício Instituto Bíblico de Roma. Bíblia Sagrada. São Paulo, Edições Paulinas 1965.

8. Almeida JF. A Bíblia Sagrada. Antigo e Novo Testamento. Barueri, Sociedade Bíblica do Brasil, 1998:434-435.

9. Bible: Revised Standard Version, $2^{\text {nd }}$ ed. Stonehill Green, Bible Society Swindon,1971.

10. Die Bibel - Nach der Übersetzung Martin Luthers. Stuttgart, Deutsche Bibelgesellschaft, 1999:624.

11. Die Bibel. Die ganze Heilige Schrift des alten un neuen Testaments. Amerikanischen Bibel-Gesellschaft, 1885.

12. Het Boeh: een eigentijdse verwoording van de Bijbel. Heerenveen, Uitgeverij Jongbloed, 2001:535

13. Sazalis HE. Tradutora pública da língua grega. Junta Comercial de São Paulo, 2008 (comunicação pessoal).

14. Arnold BT, Beyer BE. Descobrindo o Antigo Testamento. São Paulo. Cultura Cristã, 2001:26-28 